\title{
Measuring E-Satisfaction Of Interactive Online Communication System
}

\author{
Yoon C. Cho, (Email: yoonji22e@gmail.com), Hawaii Pacific University
}

\begin{abstract}
This paper is based on the premise that the current growth of successful application of "I-Way" in a number of different business settings suggests that the traditional economic activities of old are suffering a profound transformation. While numerous researches have examined effectiveness of ebusinesses, not many studies have investigated factors that affect effectiveness of online communication system. Therefore, in this paper, the authors investigate what factors affect ease of use and usefulness and then how ease of use and usefulness affect attitudes toward online communication system and user satisfaction. This study applied classification of different user groups based on their degree of involvement to measure different levels of perceived ease of use and usefulness. Uses and gratification theory (Herzog 1944; McGuire 1974; Luo 2002) has been applied in this study to explain users' attitudes toward online communication system and user satisfaction. This study found that customers' attitudes towards online communication system significantly impact the level of esatisfaction. The findings of the study contribute to the development of the uses and gratification theory by applying it to users' attitudes toward online communication system. Further, this study provides implications and offers suggestions to e-businesses dealing with communication system.
\end{abstract}

\section{INTRODUCTION}

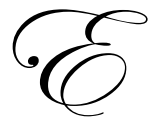

lectronic commerce relies on "customer or user interactions" via a computer and telecommunications infrastructure for the purpose of advertising, promoting, and selling products and services online.

This paper views e-commerce, e-business, and the emergent I-Way economy as a "virtualization" of product/service/knowledge/information exchanges. By virtualization, we mean that parties involved in exchanges use computer-mediated communication (CMC) systems as a means of establishing interpersonal, inter-organizational, intra-organizational contact. The "telepresence" created by this virtualization process, enables individuals, organizations and automated systems to coordinate all aspects of consumer buying process.

This paper is based on the premise that Internet, as an interactive computer-mediated communication (CMC) systems create "culture" to online users and e-businesses build strategies to valued customers. This paper addresses that the power of online groups have greatly affected to the online culture and user opinions. Examples include i) feedback systems (e.g., cnet.com, epinons.com), which provide and share pros- and cons- about specific brands/company/store to potential and existing consumers; ii) group buying sites, which consist of consumer group and strive to create a community of cost-conscious buyers (Mohammed 2004); and iii) auction sites, which allows consumer share information and buy/sell products. The Internet, as a new model for hypermedia Computer-Mediated Environments (CMEs: Hoffman, Novak, and Chatterjee 1995) allows customers and firms frequently interact each other. The Internet was intended in part as a community building technology that would allow users to share data, knowledge, and opinions in a real-time online environment (Hiltzik 1999). The Internet's interactivity had allowed individuals to transcend the traditional limitations of offline community (Mohammed et al. 2004). Depending on the interactivity, usage on email or messenger system or online community is quite varied. Users' involvement and the degree of involvement in Internet system have been interpreted as interactivity and individualization (2Is). 2Is are known as online community-related attitudes (Mohammed et al. 2004). Customers are able to customize or individualize email, messenger, and community system and frequently interact with other users in the context of online environment. However, depending on the degree of interactivity, customers' attitudes toward such systems are 
quite varied. This study stressed that e-businesses should successfully develop stages of customer relationship that include awareness, exploration, commitment, and dissolution (Mohammed 2001). This study also applied levels of relationship marketing that are suggested by Strauss, El-Ansary, and Frost (2003). Another view of levels of relationship marketing includes three levels by considering factors, such as primary bond, potential for sustained competitive advantage, main element of marketing mix. Based on the consideration above, the purpose of this study is to explore 1) the factors affecting online users' attitudes toward online communication system, such as email, messenger, and community; 2) how those factors affect perceived easy of use and usefulness; 3) the effects of perceived easy of use and usefulness on overall attitudes toward the online communication system; 4) how overall attitudes toward sites affect user satisfaction; and how online users' attitudes toward websites differ from individual users' various level of involvement.

\section{OVERVIEW OF ONLINE COMMUNICATION SYSTEM}

Community is a set of interwoven relationships, built upon shared interests, that satisfies individual needs that would otherwise be unattainable (Mohammed 2004). Mohammed (2004) posits that relationships imply a higher degree of commitment and intensity between individuals, whereas interactions can involve communication at a very basic, noncommittal level. The degree of interactions and relationships are related to the online communication system including email, messenger, and community system. Users send/receive email messages with other users who even don't have higher degree of relationships, therefore it is a tool for interactions rather than building higher degree of relationships. However, users for messenger system and online community mainly interact with other users based on the degree of relationships. Therefore, those are tools to deepen relationships, but not just interactions.

Communication tools are at the heart of online community (Hanson 2000). Early communication system has been developed from email to Internet Messenger system (IM) and online community. According to Hanson (2000), types of community building tools consist of communication rings (e.g., email lists, net pagers, groupware, and games and simulations) and content trees (e.g., Usenet, bulletin boards, chat rooms, virtual worlds, and websites). Online communication rings include a) email networks, which demonstrate one of the main communication structures for online community building and instant messaging service, which is the best for unstructured, quick communication (Hanson 2000); ii) electronic groups, such as intranet and extranet, which employees in a corporation with access to a company network or the Internet formed a group online (Sproull \& Kiesler 1991); iii) groupware, which encompasses technologies that lead to collaboration and sharing between members; and iv) online games and simulations, which can stimulate communication and serve as a discussion ring (Hanson 2000). Content trees include i) discussion groups such as Usenet, ii) thousands of different dedicated bulletin boards and discussion threads, iii) public chat rooms organized by topic, and iv) Web sites with member content (Hanson 2000). Online communities function can also classified into i) real-time systems, such as Internet Relay Chat (IRC), real-time chat, and virtual worlds and MUDs/MOOs (multi-user dimensions/MUDs object oriented) and ii) asynchronous systems, such as mailing lists, newsgroups (Usenet groups), and Web-based message boards (i.e., bulletin board systems) (Mohammed et al. 2004). Online community function, from a broad operational level, in one of two primary ways (Mohammed et al. 2004). Mohammed (2004) addressed that users communicate through either real-time formats (i.e., instant communication where messages are sent, read, and replied to immediately) or asynchronous formats (i.e., delayed communication, where the time between message being sent, read, and replied to can vary greatly).

Three broad types of communities, which classified by their foundation of shared interests include information-driven communities, activity-driven communities, and commonality-driven communities (Mohammed et al. 2004). Members at information-driven communities exchange trading tips, voice opinions on the market, and discuss various companies (e.g., vintagebus.com, Motley Fool), while members at activity-driven communities more actively involve in community activities, such as sharing an interest in buying and selling goods (e.g., ebay.com, station.com) (Mohammed et al. 2004). Members at commonality-driven communities share interests arise out of commonalities such as sharing the same profession or ethnicity (e.g., mamamedia.com (kids), thirdage) (Mohammed et al. 2004). 
Table 1: The Community Growth Path (Mohammed, Fisher, Jaworski, And Cahill 2004)

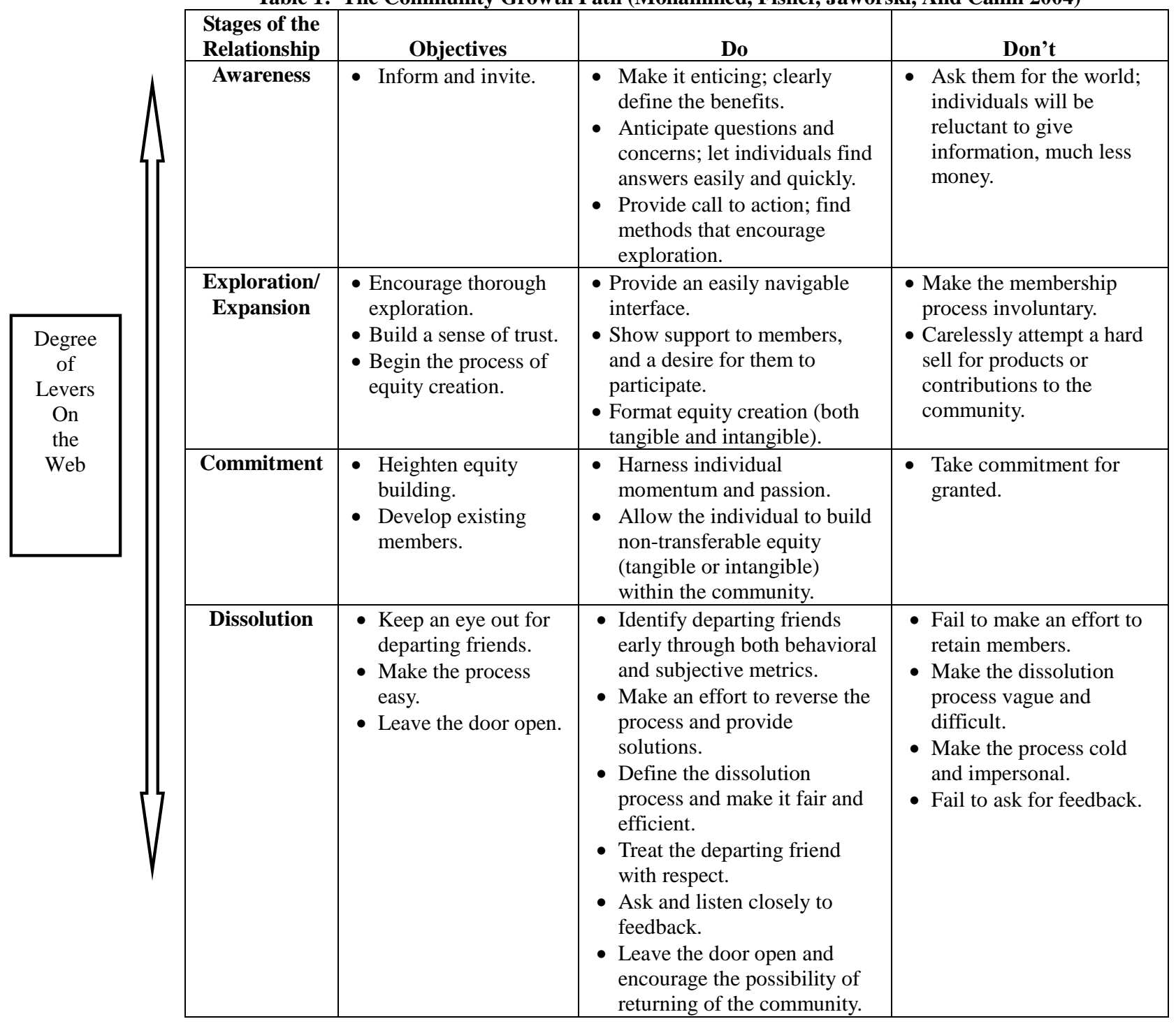

Users' involvement on the online community has been varied on different levels. Among the three levels of relationship marketing that are proposed by Strauss, El-Ansary, and Frost, (2003), managing online community is one of the strategies for a level two relationship and customization service is a good example of deeper level of relationship. Assuming that Internet users' attitudes toward websites are quite varied based on their levers on websites, this study uses the framework the levers across the stages, proposed by Mohammed (2002). The levers, which were introduced based on different stages to classify the factors that account for the success of the online marketing strategies, have applied in this study (Mohammed 2002; Cho and Ha 2004). Mohammed et al. (2004) proposed three different levels of community including nascent level, formative level, and mature level for four characteristics, such as people (i.e., members), process, culture, and technological characteristics. Depending on users' interactivity, four relationship stages including awareness, exploration/expansion, commitment, and dissolution stages have been frequently applied for attitudes toward websites (see table 1: Mohammed et al. 2004). Similarly, Amy Jo Kim (2000)'s classification of online community users, called "membership life cycle," includes visitors, novices, regulars, leaders, and elders. The role of 2Is has significantly affected to the degree of levers of online community. Mohammed et al. (2004) stated that individualization and interactivity are at the core of relationships, and hence online communication 
systems. Previous studies (Hanson 2000) stated that loyalty and commitment lead to more time online and more indepth relationships and member content. Hanson (2000) also stated that member profiles and transaction offerings are increasing returns closely connected to the profitability of the online communication systems. This study considers three online communication systems, such as email, instant messenger, and online community. Table 2 presents the different functions and services that are offered by online community systems and also based on the degree of involvement.

Table 2: Classifying Functions/Services That Are Offered By Online Communication System

\begin{tabular}{|c|l|l|l|}
\cline { 2 - 4 } \multicolumn{2}{c|}{} & \multicolumn{2}{|c|}{ Continuum of the Degree of Involvement on the Website } \\
\hline $\begin{array}{c}\text { Online } \\
\text { Communication } \\
\text { System }\end{array}$ & \multicolumn{1}{|c|}{ Basic Level } & \multicolumn{1}{|c|}{ Mid-Level } & \multicolumn{1}{c|}{ Advanced Level } \\
\hline Email System & $\begin{array}{l}\text { Sending/Receiving email } \\
\text { messages. }\end{array}$ & $\begin{array}{l}\text { Privacy \& security: effective } \\
\text { spam filtering system, virus } \\
\text { scanning system, Email } \\
\text { downloading time, attachment } \\
\text { speed, options for storage } \\
\text { capacity, address book service. }\end{array}$ & $\begin{array}{l}\text { Advanced options for spam } \\
\text { filtering system, use customized } \\
\text { system, block address. }\end{array}$ \\
\hline $\begin{array}{c}\text { Instant } \\
\text { Messenger }\end{array}$ & $\begin{array}{l}\text { Changing font size and colors, } \\
\text { email/people search, use } \\
\text { customer help, share/send photos } \\
\text { and files. }\end{array}$ & $\begin{array}{l}\text { Visability/audibility (video } \\
\text { conferencing system, webcam } \\
\text { chat, voice chat), customized } \\
\text { systems, such as managing } \\
\text { online characters (i.e., avatars), } \\
\text { managing calendar, block } \\
\text { address, mobile access. }\end{array}$ \\
\hline $\begin{array}{c}\text { Online } \\
\text { Community }\end{array}$ & $\begin{array}{l}\text { Sharing information by posting } \\
\text { and reading content, and } \\
\text { participating in discussion } \\
\text { forums. }\end{array}$ & $\begin{array}{l}\text { Sharing photos, buying or selling } \\
\text { products. }\end{array}$ & $\begin{array}{l}\text { Visability/audibility (video } \\
\text { conferencing system, webcam } \\
\text { chat, voice chat), customized } \\
\text { systems, build member loyalty, } \\
\text { promote member to member } \\
\text { interaction. }\end{array}$ \\
\hline
\end{tabular}

\section{CONCEPTUAL FRAMEWORK}

Involvement theory, which has been often studied in the traditional marketing, also applied in this study for online context. In traditional marketing, involvement has been adopted in the study of purchase decisions (Clarke and Belk 1978), advertisements (Krugman 1977), or products (Howard and Sheth 1969), etc. For example, involvement with purchases leads one to search for more information and spend more time searching for the right selection (Zaichkowsky 1985). Past studies in the online context have considered the degree of involvement as a predictor of technology acceptance (Stafford and Stern 2002). Stafford and Stern (2002) summarized the opinions on involvement that perceived ease of use is superior to involvement (Venkatesh and Davis 2000), while others argue that "subjective experiences such as involvement" ultimately drive behavior (Webster and Martocchio 1992). Degree of involvement in this study has been treated as a mediator to affect perceived usefulness and ease of use for online communication system. This study adopted this framework by positing that proposed different levers could be explained to group different users' usages of the websites. This study assumed that the levers are on the continuum of the degree of involvement on the websites. Thus, when users are in the stage of higher degree of web usage, such as commitment, their involvement on the website is also higher. In other words, the degree of involvement on the online communication system increases from novice to commitment considering the levers on the continuum. Therefore, this study hypothesized that user involvement increases when the levers on online communication system are commitment rather than awareness or expansion. 
Other theories in the field of social psychology, sociology, and communication studies, have addresses social presence, identity, and relationship. Social presence theory, proposed by Short, Williams, \& Christie (1976) speaks about how successfully media convey a sense of participants being physically co-present. Media richness theory is similar to social presence but it has a media-oriented perspective and was developed ten years later, with, apparently, little knowledge of earlier work on social presence (Daft and Lengel 1986; Rice 1993). Social network theory (Wellman 1997; Wellman and Frank 2001), which examines the patterns and characteristics of social connections and their relationship to individuals' lives and societal organization, also applied in this study of users' attitudes toward online communication systems. Well-known satisfaction theories that have explained consumer attitudes in brick-andmortar businesses, such as contrast theory (Engel and Blackwell 1982; Cardozo 1965) and dissonance theory (Festinger 1957) have been applied in this study of click-and-mortar businesses. Yi (1990) reviewed several theories that have been suggested to explain the effects of expectation and disconfirmation on perceived product performance. Theories of product performance differ in predicting the effects of expectations and disconfirmation, and in specifying the conditions under which the effects are likely to occur (Yi 1990). Involvement theory also has been applied in this study. Degree of involvement has been treated as a mediator to affect perceived usefulness and ease of use (EOU) for online communication system.

This study applied Uses and gratification theory (Herzog 1944; McGuire 1974; Luo 2002) for the development of conceptual model. Uses and gratification theory (Herzog 1944; McGuire 1974; Luo 2002) has been applied in this study to explain users' attitudes and consumer satisfaction toward online communication system. Uses and gratification theory has been developed from research in the context of traditional media, such as TV, magazines, or radio (Herzog 1944; McGuire 1974). It has been extended to research in the context of the online environment (e.g., Luo 2002). Recent studies, held in the online context, frequently measure web usage, attitudes toward websites, and satisfaction (Korgaonkar and Wolin 1999; Chen and Wells 1999; Luo 2002). Application of uses and gratification theory in the online context has drawn the attention of scholars since the Internet, as an interactive multimedia tool, has become a place that provides a new, many-to-many communications model and dramatically alters the traditional view of communication media (Hoffman \& Novak, 1995). The present study has been supported by another theory, proposed by Ajzen and Fishbein (1980) and often used in behavioral research. The Theory of Reasoned Action (TRA), which suggests that individuals' performance of a given behavior is primarily determined by their intention to perform that behavior. Further, researchers criticized the Theory of Reasoned Action (TRA) for not explaining the beliefs that are operative for a particular behavior, which is related to the usage of information technology (Succi and Walter 1999). Thus, the Technology Acceptance Model (TAM) has been proposed by Davis (1989a and b) to explain specific behavior from electronic commerce. The Technology Acceptance Model has been widely used in the study of online user behavior explaining the effect of perceived usefulness, perceived ease of use, and user acceptance of information technology. The TAM model has been adopted in this study to describe consumer behavior in the online environment. The model explains why online users accept or reject websites and how their internal beliefs and attitudes affect their usage behavior (Davis 1989b; DeSantics 1983; Ives, Olson, and Baroudi 1983).

Therefore, within the uses and gratification framework and the theory of reasoned action, this study investigates how online communication system can be an interactive marketing tool for online users by exploring factors that affect perceived ease of use (EOU) and usefulness (U). Particularly, this study classifies factors that can be used to measure perceived ease of use and usefulness. Factors, proposed in this study include information, price, product/service, convenience, technology \& usability, brand name, promotional, and entertainment factor. This study also measures the impact of such factors to the users' attitudes toward the specific website, i.e., online communication system. The study also measures how consumers' attitudes toward specific websites affect their customer/user satisfaction or behavior intention to use. User satisfaction has been obtained from the current users and behavior intention to use from the potential users of online communication system. For current users, the present study adopted the levers, suggested by Mohammed (2002), across the stages of online communication system to see whether those factors have a different impact on user satisfaction based on a different extent of individual user's usage on information systems (see figure 1).

The proposed model of this study is determined by the different factors that arouse perceived ease of use and usefulness and also dummy variables for the levers across the stages on online communication system with coefficients. In this study, perceived usefulness and ease of use are considered predictors to investigate the external 
variables that affect users' acceptance of online communication system. Both variables, perceived usefulness and perceived ease of use, are the equivalent of internal beliefs $\left(b_{i}\right)$ from the Theory of Reasoned Action (TRA).

$\mathbf{H}_{1}$ : As perceived usefulness (U) on online communication system is greater, users' positive attitudes increase.

$\mathbf{H}_{1 \mathbf{a}}$ : The degree of perceived usefulness (U) will be higher as the degree of user involvement on online communication system increases.

$\mathbf{H}_{2}$ : As perceived ease of use (EOU) on online communication system is greater, users' positive attitudes increase.

$\mathbf{H}_{2 \mathrm{a}}$ : The degree of ease of use (EOU) will be higher as the degree of user involvement on online communication system increases.

Figure 1: The Proposed Model Of Users' Attitudes Toward Online Communication System \& E-Satisfaction

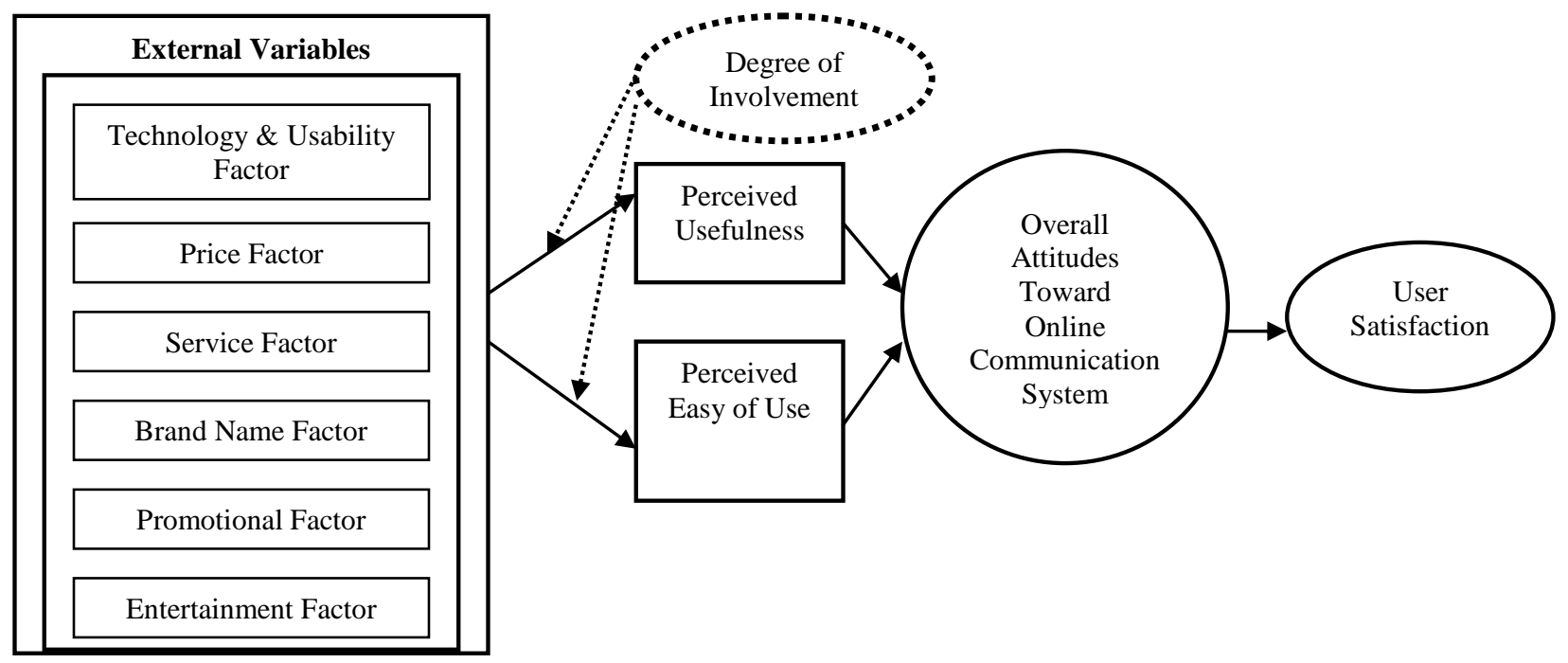

\section{Attitudes Toward Online Communication System And User-Satisfaction}

Attitudes toward a website have been often considered as a variable to measure the effectiveness of websites, systems, or Internet advertising (e.g., Zhou 2002; Chen and Wells 1999). Previous researchers found that attitudes toward a site are quite measurable (Gibson 1997). Compared to the attitudes toward offline shopping, researchers have often investigated attitudes toward the usage of computer and perceptions of the competence and productivity of computers (Zoftan and Chapanis 1982). Researchers (Zoftan and Chapanis 1982) found that those with higher attitudes view computers as more efficient, dependable, precise, and organized. Prior studies also addressed that attitudes toward computers have important effects on the usage and ultimate success or failure of computer systems (Webster and Martocchio 1992: Igbaria et al. 1990). Schubert and Selz (1999) proposed criteria to measure e-business effectiveness. Criteria for four proposed phases, including information, agreement, settlement phases and community component, have been introduced in the study by Schubert and Selz (1999). Further, attitudes toward Web sites have been discussed to measure the ease of building a relationship with a business, website loyalty, e-satisfaction with the site or service provided by the business, length of time to stay on a website, or a comparison analysis between or among the sites (Chen and Wells; Schubert and Selz 1999; Cho et al. 2002). Thus, we hypothesized that positive attitudes toward websites increase e-satisfaction for existing customers of online communication system. Authors classified four different types of customers to measure attitudes toward online communication system depending on their degree of involvement. The current study considers the degree of involvement as a mediating variable based on the suggested model (Figure 3). Degree of involvement has been considered in this study as factors such as number of years, number of times logged on to online communication system, affect consumers' attitudes toward sites. 
The traditional market places emphasize "customer satisfaction" as a way to earn consumer loyalty and attract new customers. Previous studies (Cho and Fjermstad 2005) have examined the firm's approach to Customer Relationship Management (CRM) in order to account for the new realities of market spaces. This study measures the impact of overall attitudes toward sites to the e-satisfaction.

Previous studies have posited that maximizing customer satisfaction and maintaining customer loyalty are major components for E-Commerce Customer Relationship Management (eCRM). In an effort to provide a positive contrast for the new against the old, this paper addresses the issue of customer satisfaction and customer loyalty as being at the center of successful click-and-mortar business exchanges (Cho and Fjermstad 2005). The author focuses more on the customer satisfaction because it provides clues as to what managerial changes might have induced different and more desirable behaviors, raising the issue of customer loyalty myopia. Satisfaction/Dissatisfaction theories such as cognitive dissonance theory (Festinger, 1957), contrast theory (Engel and Blackwell, 1982; Howard and Sheth, 1969; Cardozo, 1965), assimilation-Contrast Theory (Oliver, 1997), expectation - disconfirmation theory (Oliver and Desarbo, 1988), level of aspiration (LOA) theory (Yi, 1990), and adaptation level theory (Helson, 1948, 1959, and 1964) have applied in this study to measure e-satisfaction. Other theories such as comparison-level theory, equity theory, and value-percept disparity theory have also been applied for explaining e-customer satisfaction.

$\mathbf{H}_{3}$ : As positive attitudes toward online communication system increases, the degree of user satisfaction also increases.

$\mathbf{H}_{3 \mathbf{a}}$ : Positive attitudes toward online communication system will be higher as the degree of involvement on the Websites increases.

\section{PROPOSED FACTORS THAT AFFECT ATTITUDES TOWARD ONLINE COMMUNICATION SYSTEM}

\section{Technology And Usability Factor}

Online communication system not just adopts new technologies, but must consider usability factors to meet ultimate customer needs and wants. Prior studies discussed how perceived usefulness and ease of use are influenced by various factors, including the system's technical design characteristics (Benbasat and Dexter 1986; Dickson, DeSanctis, and McBride 1986; Malone 1981). Technology factors include website effectiveness such as speed and customer interface design factors (Mohammed 2002), such as content, context, and customization. Technology and media-inherent factors, proposed by Schubert and Dettling (2002), are applied in this study. The extended Web Assessment Method (EWAM), proposed by Schubert and Dettling (2002), focuses on the special features that are inherent in the Internet. This study selected criteria, related to the technology factor from the Web Assessment Model, which was proposed by Schubert and Selz (1999), prior to EWAM. Based on the suggested phases (e.g., settlement, agreement, and information phases) from the Web assessment model, criteria, related to the technology factor at each stage, such as good user interface, structure of content, adjustable customer profile, and possibility of customized products, are used in this study. Another framework for technology-mediated customer interface by Mohammed et al. (2000), called 7Cs, which form the basis of an effective interface, including context, content, community, customization, communication, connection, and commerce. Mohammed et al. (2000) also addressed the extent to which all of the 7Cs work together to support the value proposition and business model (i.e., Fit and Reinforcement) is vital for successful e-businesses. Successful online communication systems have developed marketing strategies considering 7Cs by considering product selection, changing plans, payment system options, in-flight menu selection, seat selection, and 2Is (i.e., individualization and interactivity). This study hypothesized that user perception of the technology \& usability factor of online communication system is positively associated with perceived usefulness and perceived ease of use.

$\mathbf{H}_{4}$ : User perception of the technology \& usability factor of online communication system is positively associated with both perceived usefulness and perceived ease of use.

$\mathbf{H}_{4 \mathrm{a}}$ : The impact of the technology \& usability factor on perceived usefulness and ease of use will be higher as the degree of user involvement on online communication system increases. 


\section{Price Factor}

Previous researchers stated that price is a major factor to measure consumer sensitivity (Krishnamurthi and Raj 1988). The price factor has a large role in the choice and quantity of buying decisions (Krishnamurthi and Raj 1988). Price affects online users' perception both positively and negatively. Hanson (2000) posits that the Internet will raise or lower price sensitivity among customers. Price sensitivity might increase in the online environment due to the availability of price comparisons on the Web. Many online companies provide services, such as price and service comparisons, so customers can easily compare the price with the various service options. With the online communication systems, customers pay for more capacity in case of email, for avatar or emoticons in case of messenger system, or avatar, wall-paper, music, and other accessories for online community. This study hypothesized that users' perception of the price of online communication system affect perceived usefulness and perceived easy of use.

H5: User perception of the price factor of online communication system is positively associated with both perceived usefulness and perceived ease of use.

H5a: The impact of the price factor on perceived usefulness and ease of use will be higher as the degree of user involvement on online communication system increases.

\section{Service Factor}

Online communication system provides important information about changes of membership services, changes on capacity information, updates, etc. Previous studies addressed how businesses offer and maintain product/service quality is success factor for E-Commerce Customer Relationship Management (eCRM). Other studies also found that customer service failure also becomes often a cause of customer complaints (Cho, Hiltz, and Im 2003). Various researchers have addressed the importance of technology that enhances service quality. For example, Bitner, Booms, and Tetreault (2000) found that technology is incorporated into the service-marketing triangle, both supporting and facilitating service delivery. A study by Bitner et al. (2000) also discussed the role of technology in implementing effective service recoveries and encouraging customer complaining (see also Brown 1997 and Shaffer 1999). Most online firms manage Web-based customer service centers to deal with customer comments and complaints, utilizing sophisticated technology (Cho et al. 2002). This study hypothesizes that users' perception of the product/service quality of online communication system positively affects perceived usefulness and ease of use, as proposed by Davis (1989a and b).

H6: User perception of the product and service factor of online communication system is positively associated with both perceived usefulness and perceived ease of use.

H6a: The impact of the product and service factor on perceived usefulness and ease of use will be higher as the degree of user involvement on online communication system increases.

\section{Brand Name Factor}

The role of brand has been frequently addressed in previous studies. Traditionally, brand names serve a variety of purposes for consumers and advertisers (Meyers-Levy 1989). Various researchers (e.g., Levy 1989) have noted that firms with extremely memorable brand names often regard those names as their most valuable asset because these labels provide immediate recognition, and often, acceptance of new products that may be introduced under the brand name. This study points out that the role of a brand name is also significant in the online environment. Consumers $\log$ on to certain websites based on their recognition of the brand names. The role of the URL (Uniform Resource Locator), which represents the online business, is also important as online consumers recall the e-commerce sites depending on how much the URL is memorable (Cho and Ha 2003). Therefore, brand names could help consumers make purchase decisions in the computer - mediated environment as they enable highly reliable inferences about consumption benefits after one purchase and use (Alba et al. 1997). Keller (1993) also posited that the stronger the brand image held in the consumers' memories, the more likely they will purchase those products without any additional decision making. However, as Dick et al. (1990) pointed out, brand attribute value inferences depend on the 
accessibility of information. This study hypothesizes that brand name importantly affects consumer choice behavior in the electronic marketplace.

$\mathbf{H}_{7}$ : User perception of the brand name factor of online communication system is positively associated with both perceived usefulness and perceived easy of use.

$\mathbf{H}_{7 \mathbf{a}}$ : The impact of the brand name factor on perceived usefulness and ease of use will be higher as the degree of user involvement on online communication system increases.

\section{Promotional Factor}

E-businesses use the Internet for various promotional tools. First, the Internet can be a viral marketing tool, which is the online equivalent of Word of Mouth (WOM: Hanson 2000) for industries. According to Hanson (2000), the Net amplifies the power and accelerates the speed of feedback from users to potential adopters. According to emarketer.com (2004), goals of online advertising is to retain customers and increase loyalty (63\%); to acquire new customers (62\%), to create awareness of new product (59\%); to encourage trial (55\%), and to keep and establish product "top of mind" (50\%). While effectiveness of online advertising (i.e., banner ads) used to be very low (e.g., average click through rate is only about $1 \%$ ), online advertising is still effective to increase brand awareness and loyalty. Compared to banner ads, click through rate for email advertising is quite (on average about $80 \%$ ) as customers received email ads based on their permission and preference. Online businesses often use email and other advertising for sales promotional tools. This study hypothesized that promotional factor affects consumer behavior of online communication system.

$\mathbf{H}_{\mathbf{8}}$ : User perception of the promotional factor of online communication system is positively associated with both perceived usefulness and perceived easy of use.

$\mathbf{H}_{\mathbf{8 a}}$ : The impact of the promotional factor on perceived usefulness and ease of use will be higher as the degree of user involvement increases.

\section{Entertainment Factor}

Prior studies (e.g., Danet et al. 1996a) note that computer-mediated communication (CMC) is strikingly playful. Various studies have recognized the inherently playful nature of the computer as medium (e.g., Danet et al. 1996b; Rafaeli, 1984, 1986; Kuehn, 1993; Lanham, 1993; Ruedenberg et al., 1995). Danet et al. (1996a and b) also mentioned that millions of people are playing with their computer keyboards in various ways, thus an application of computers to theater-related purposes is perhaps inevitable. Researchers (Webster and Martocchio 1992) argue that microcomputer playfulness represents a degree of cognitive spontaneity in computer interactions. Playfulness is an important factor to acquaint with the computer, by shifting attitudes from fearful and awesome aspects to positive factors (Webster and Martocchio 1992; Gardner et a. 1989; Howard and Smith 1986). It is also viewed as the capacity to draw satisfaction from the immediate intellectual development of a topic, irrespective of any ulterior motive (Dewey 1913).

Social escapism motivation refers to consumers' motives for using the Web as a reliever of day-to-day boredom and stress (Zhou 2002: Korgaonkar and Wolin 1999). Online communication system is a pleasurable, fun, and enjoyable activity that allows one to escape from reality (Zhou 2002). As Zhou (2002) cited, users may perceive online communication system as more entertaining than informative. Therefore, this study separates the entertainment factor for online communication system from the information factor to investigate the effects to the perceived usefulness and ease of use. This study proposes that users' perceptions about online communication system as an entertainment factor significantly affect their perceived usefulness and ease of use.

$\mathbf{H}_{9}$ : User perception of the entertainment factor of online communication system is positively associated with both perceived usefulness and perceived easy of use.

$\mathbf{H}_{9 \mathbf{a}}$ : The impact of the entertainment factor on perceived usefulness and ease of use will be higher as the degree of user involvement increases. 


\section{Methodology}

The study conducted a survey with three hundred fifty randomly selected subjects in the U.S. Subjects are online users and have usage experience with the Internet. Quantitative methods, including factor and regression analyses and ANCOVA (Analysis of Covariance), were applied to measure the online users' attitudes towards online communication system, ease of use, usefulness, and e-satisfaction. This study developed the scales from previous studies. For example, scales for perceived usefulness and perceived ease of use were from the study by Davis (1989) and Davis, Bagozzi, and Warshaw (1989). Scales for other variables were from studies by Succi and Walter (1999), Zhou (2002), Schubert and Selz (1999), and Chen and Wells (1999). Likert scales, Semantic differential scales, and open-ended questions were used to measure the items. For Likert scale questions, a five-point scale with extremes labeled, "Strongly Disagree" and "Strongly Agree" was used. Multivariate data analyses, such as factor and regression analyses were used to analyze this study. In order to measure the degree of involvement, this study used the scale items for each lever across the stages on online communication system, proposed by Mohammed (2002) with modifications. This study measures the average for the items for each lever, which represents the degree of involvement, e.g., average for items of novice, awareness, exploration/expansion, and commitment. Users' degree of involvement on online communication system was decided based on the average scores, obtained above. For instance, if a user has the highest score for the items of awareness, we consider that $\mathrm{s} / \mathrm{he}$ is in the stage of awareness. After the lever was found, dummy variables were used to code the data. This study used novice as a base for dummy variables.

The study found six factors that affect perceived usefulness and ease of use toward websites: "technology and usability factor," "price factor," "service factor," "brand name familiarity," "promotional factor," and "entertainment factor." The result of the regression analyses indicate that factors found in this study affect both on perceived usefulness and easy of use. Further, the results of ANCOVA showed that the impact of the factors on the perceived usefulness and easy of use was significantly different according to the users' degree of involvement on the websites. The findings of the study contribute to the development of the uses and gratification theory and Technology Acceptance Model (TAM), while also providing implications and suggestions to e-businesses.

The response rate was $90 \%$ and about $79 \%$ of respondents answered that they have ever used online communication system, including email, messenger system, and online community. Of the three hundred fifty respondents, $54.6 \%$ were male and $55.4 \%$ were female. About $18.8 \%$ were between the ages $19-20 ; 63.4 \%$ were between the ages $21-30 ; 13.2 \%$ were in the $31-40$ age group; $2.1 \%$ were in the age group $41-50$; and $2.3 \%$ were age 51 or older. Approximately $4.0 \%$ reported that their highest educational level was high school graduate, while $6.8 \%$ had an associate degree, $57.9 \%$ were still at university for undergraduate degree, and $9.9 \%$ had bachelor's degree, $13.0 \%$ were still at university for graduate degree, $8.4 \%$ had master degree or higher. About $80.8 \%$ had an annual average income between $\$ 20,000$ and $\$ 50,000$ and $51.3 \%$ were American (i.e., $28.1 \%$ were white American; $19.9 \%$ were Asian American; and 2.8\% African American), 30.8\% were Asian, 10.8\% European, and 3.4\% were Hispanic.

\section{Results}

The first step in this analysis was intended to validate the factors that affect two predictors, perceived usefulness and ease of use. This study ran the confirmatory factor analysis to identify those factors. Using principal components analysis as the extraction method and Varimax rotation methods with Kaiser Normalization, the most relevant data emerged. This analysis showed a distinct reduction of six factors, with Eigen values over 1.00. The factor analysis results including scaled items, which were grouped as a factor, Eigen values, and components are summarized in table 3. As proposed, the seven factors that affect perceived usefulness and ease of use toward online communication system appeared to be "technology and usability factor," "price factor," "service factor," "brand name familiarity," "promotional factor," and "entertainment factor."

A separate factor analysis was done to group scale items for predictors, perceived usefulness and ease of use, which affect attitudes toward websites. Scale items were developed from the previous study by Davis (1989a and b). Table 4 shows the results of factor analysis for external variables, which affect perceived usefulness and ease of use. As table 4 shows, factors, which have Eigen values over 1.00 are grouped as variables. Three items represent perceived ease of use (EOU) and four items represent perceived usefulness (U). 
Table 3: Component Matrix (Rotated)

\begin{tabular}{|c|c|c|c|c|c|c|c|}
\hline \multicolumn{2}{|l|}{ Items } & \multicolumn{6}{|c|}{ Component } \\
\hline External Factors & Scale Items & 1 & 2 & 3 & 4 & 5 & 6 \\
\hline Price II & $\begin{array}{l}\text { When I use online communication system, I } \\
\text { often consider the price. }\end{array}$ & .896 & & & & & \\
\hline Price I & $\begin{array}{l}\text { I saved a lot using online communication } \\
\text { system compared to the offline } \\
\text { communication. }\end{array}$ & .875 & & & & & \\
\hline $\begin{array}{l}\text { Technology \& } \\
\text { Usability III }\end{array}$ & $\begin{array}{l}\text { Using advanced technology for online } \\
\text { communication system gives me a pleasure. }\end{array}$ & & .837 & & & & \\
\hline $\begin{array}{l}\text { Technology \& } \\
\text { Usability II }\end{array}$ & $\begin{array}{l}\text { Web interface from online communication } \\
\text { system is very convenient to use. }\end{array}$ & & .771 & & & & \\
\hline Entertainment III & $\begin{array}{l}\text { I use online communication system for } \\
\text { pleasure. Online communication systems are } \\
\text { enjoyable. }\end{array}$ & & & .801 & & & \\
\hline Entertainment V & $\begin{array}{l}\text { With online communication system, I was } \\
\text { able to reach many people (i.e., friends, } \\
\text { relatives, etc.). }\end{array}$ & & & .724 & & & \\
\hline Service I & $\begin{array}{l}\text { Membership services from online } \\
\text { communication system are very useful. }\end{array}$ & & & & .711 & & \\
\hline Service II & $\begin{array}{l}\text { I am satisfied with service, which are } \\
\text { provided from online communication } \\
\text { system. }\end{array}$ & & & & .680 & & \\
\hline Brand Name I & $\begin{array}{l}\text { I often prefer to use well-known online } \\
\text { communication system. }\end{array}$ & & & & & .752 & \\
\hline Brand Name II & $\begin{array}{l}\text { Familiar brand names (e.g., URL) give me } \\
\text { lots of motivation when I log on the online } \\
\text { communication system. }\end{array}$ & & & & & .691 & \\
\hline Promotional II & $\begin{array}{l}\text { When I'm more likely log onto online } \\
\text { communication system when I see } \\
\text { promotions. }\end{array}$ & & & & & & .789 \\
\hline Promotional IV & $\begin{array}{l}\text { I enjoy to take benefits from promotions of } \\
\text { online communication system. }\end{array}$ & & & & & & .642 \\
\hline Eigen Value & & 4.901 & 2.300 & 1.611 & 1.543 & 1.399 & 1.120 \\
\hline
\end{tabular}

This study analyzed simple linear regression analyses and the analyses of variance (ANOVA). Factor scores were used for regression analyses. First, this study used regression analyses for the impacts of external variables to the predictors that are perceived usefulness and ease of use. The different degrees of involvement were considered as dummy variables. Since four different levers were used as different degrees of involvement, three dummy variables were added to the regression analyses. Another regression analysis was conducted to examine the effects of perceived usefulness and ease of use to the attitudes toward the online communication system (table 5-7). The following tables (table 5 for email; table 6 for instant messenger system, and table 7 for online community) present the results of the regression analyses for the effects of external variables to the perceived usefulness (U) and ease of use (EOU). Stepwise regression analysis was applied to find how indicators affect perceived usefulness and ease of use. The 
results in table 5-7 show that all external variables except the price factor affect perceived usefulness and perceived ease of use. Thus, hypotheses 4-9 - i.e., the impacts of factors, such as "technology and usability factor," "price factor," "service factor," "brand name familiarity," "promotional factor," and "entertainment factor" to perceived usefulness and easy of use were accepted, while hypothesis 5 - i.e., the impact of price factor to perceived usefulness and ease of use - was rejected. The results of the analysis of variance found the models significant at .01 level with $F$ $=15.724$ (for email, $r$-square $=.612$ ), 14.382 (for instant messenger system, $r$-square $=.696$ ), and 14.211 (for online community, $r$-square $=.612$ ).

Table 4: Component Matrix (Rotated)

\begin{tabular}{|c|l|c|c|}
\hline \multicolumn{2}{|l|}{ Scale Items* } & \multicolumn{2}{c|}{ Component } \\
\hline $\begin{array}{l}\text { External } \\
\text { Factors** }\end{array}$ & \multicolumn{1}{|c|}{} & $\mathbf{2}$ & $\mathbf{1}$ \\
\hline EOU & Interacting with the online communication system does not require a lot of my mental effort. & .881 & \\
EOU & I find it easy to get the online communication system to do what I want it to do. & .843 & .791 \\
EOU & I find it easy to recover from errors encountered while using online communication system. & \\
U & Using online communication system improves my performance. & .869 \\
U & Using online communication system increases my productivity. & .843 \\
U & Using online communication system allows me to accomplish more work than would & .810 \\
& otherwise be possible. & & .733 \\
\hline & Using online communication system saves me time. & & \\
\hline
\end{tabular}

* Scale items were modified from Davis (1989a and b). ** EOU: Perceived Ease of Use; U: Perceived Usefulness

Table 5: Summary Of The Effects Of External Variables On The Perceived Usefulness (U) And Perceived Easy Of Use (EOU) By The Degree Of Involvement: Email System

(Awareness $N=80$, Exploration/Expansion $N=153$, Commitment $N=117$ )

\begin{tabular}{|c|c|c|c|c|c|c|}
\hline \multirow[t]{3}{*}{ Variable } & \multicolumn{6}{|c|}{ Standard Coefficient* And Significance } \\
\hline & \multicolumn{2}{|c|}{ Awareness } & \multicolumn{2}{|c|}{ Exploration/Expansion } & \multicolumn{2}{|c|}{ Commitment } \\
\hline & $\mathbf{U}$ & EOU & $\mathbf{U}$ & EOU & $\mathbf{U}$ & EOU \\
\hline Technology \& Usability Factor & $\begin{array}{c}.229 \\
\left(2.465^{*}\right) \\
\end{array}$ & $\begin{array}{c}.239 \\
(2.825 *) \\
\end{array}$ & $\begin{array}{c}.239 \\
\left(3.275^{* *}\right) \\
\end{array}$ & $\begin{array}{c}.274 \\
\left(3.026^{* *}\right)\end{array}$ & $\begin{array}{c}.313 \\
(4.752 * *) \\
\end{array}$ & $\begin{array}{c}.411 \\
\left(5.855^{* *}\right)\end{array}$ \\
\hline Price Factor & $\begin{array}{c}.221 \\
(2.133 *)\end{array}$ & $\begin{array}{c}.143 \\
(1.919)\end{array}$ & $\begin{array}{c}.103 \\
(1.046)\end{array}$ & $\begin{array}{c}.153 \\
(1.654)\end{array}$ & $\begin{array}{c}.158 \\
(2.112)\end{array}$ & $\begin{array}{c}.110 \\
(1.913)\end{array}$ \\
\hline Service Factor & $\begin{array}{c}.132 \\
(1.542)\end{array}$ & $\begin{array}{c}.241 \\
(2.338 *)\end{array}$ & $\begin{array}{c}.243 \\
(2.992 * *)\end{array}$ & $\begin{array}{c}.281 \\
\left(2.910^{* *}\right)\end{array}$ & $\begin{array}{c}.585 \\
(6.764 * *)\end{array}$ & $\begin{array}{c}.512 \\
(6.584 * *)\end{array}$ \\
\hline Brand Name Factor & $\begin{array}{c}.251 \\
(2.787 *)\end{array}$ & $\begin{array}{c}.207 \\
(1.816)\end{array}$ & $\begin{array}{c}.222 \\
(2.432 *)\end{array}$ & $\begin{array}{c}.290 \\
\left(3.319^{* *}\right)\end{array}$ & $\begin{array}{c}.364 \\
(4.521 * *)\end{array}$ & $\begin{array}{c}.410 \\
(5.299 * *)\end{array}$ \\
\hline Promotional Factor & $\begin{array}{c}.261 \\
(2.897 *)\end{array}$ & $\begin{array}{c}.248 \\
\left(2.375^{*}\right)\end{array}$ & $\begin{array}{c}.276 \\
\left(3.011^{*}\right)\end{array}$ & $\begin{array}{c}.288 \\
(2.987 * *)\end{array}$ & $\begin{array}{c}.456 \\
(5.431 * *)\end{array}$ & $\begin{array}{c}.534 \\
(6.312 * *)\end{array}$ \\
\hline Entertainment Factor & $\begin{array}{c}.243 \\
\left(2.585^{*}\right)\end{array}$ & $\begin{array}{c}.267 \\
(2.741 * *)\end{array}$ & $\begin{array}{c}.271 \\
(3.009 * *)\end{array}$ & $\begin{array}{c}.321 \\
\left(4.119^{* *}\right)\end{array}$ & $\begin{array}{c}.408 \\
\left(5.140^{* *}\right)\end{array}$ & $\begin{array}{c}.405 \\
(5.098 * *)\end{array}$ \\
\hline
\end{tabular}

** Significant at 0.01 level (2-tailed). *Standard coefficients show the effects of the three levers, such as awareness, exploration/expansion, and commitment, while novice was used as a base.

ANCOVA (Analysis of Covariance) was also applied in this study in order to examine the effect of the degree of involvement. Those results of the ANCOVA, regression analysis and ANOVA were used to test hypotheses. This study used dummy variables to test the differential effects of external variables by the degree of involvement on perceived usefulness and ease of use. The findings of regression analyses indicate that the impacts of external variables on perceived usefulness and ease of use are higher if the degree of involvement is higher. For example, this impact scored higher when the degree of involvement is in the stage of commitment rather than in the awareness stage. Further, the results of ANCOVA showed that the impact of the external variables on the perceived usefulness and ease of use was significantly different according to the degree of involvement $(F=9.133,8.153, \& 8.012$, Eta-squared $=.134, .132, \& .143$, significant at .01 level $)$. 
Another regression analysis was conducted to see how attitudes toward online communication systems are affected by perceived usefulness and ease of use. Table 8 shows the results of regression analysis for the impact of $U$ and EOU to the attitudes toward online communication systems. The results of analysis of variance found that overall, the regression model is significant $(F=13.511$, significant at .01 level, two-tailed, $r$-square $=.715)$.

This study also found the impacts of the attitudes toward online communication systems to the e-satisfaction. Two separate regression analyses were used to measure the impacts. The study found that attitudes toward online communication systems significantly affect both e-satisfaction.

Table 6: Summary Of The Effects Of External Variables On The Perceived Usefulness (U) And Perceived Easy Of Use (EOU) By The Degree Of Involvement: Messenger System

(Novice $N=62$, Awareness $N=84$, Exploration/Expansion $N=175$, Commitment $N=113$ )

\begin{tabular}{|l|c|c|c|c|c|c|}
\hline \multirow{2}{*}{ Variable } & \multicolumn{7}{|c|}{ Standard Coefficient* And Significance } \\
\cline { 2 - 7 } & \multicolumn{2}{|c|}{ Awareness } & \multicolumn{2}{c|}{ Exploration/Expansion } & \multicolumn{2}{c|}{ Commitment } \\
\cline { 2 - 7 } & U & EOU & U & EOU & U & EOU \\
\hline Technology \& Usability Factor & .311 & .278 & .338 & .314 & .291 & .227 \\
& $\left(4.061^{* *}\right)$ & $\left(3.215^{* *}\right)$ & $\left(4.681^{* *}\right)$ & $\left(4.311^{* *}\right)$ & $(3.887 * *)$ & $\left(3.195^{* *}\right)$ \\
\hline Price Factor & .090 & .139 & .131 & .187 & .189 & .152 \\
& $(1.019)$ & $(2.001)$ & $(1.112)$ & $(1.898)$ & $(1.940)$ & $\left(1.221^{* *}\right)$ \\
\hline Service Factor & .213 & .223 & .261 & .273 & .310 & .305 \\
& $\left(2.561^{* *}\right)$ & $\left(2.719^{* *}\right)$ & $\left(2.711^{* *}\right)$ & $\left(3.079^{* *}\right)$ & $\left(4.077^{* *}\right)$ & $\left(4.019^{* *}\right)$ \\
\hline Brand Name Factor & .289 & .193 & .258 & .242 & .314 & .231 \\
& $\left(3.015^{* *}\right)$ & $\left(2.271^{* *}\right)$ & $\left(2.945^{* *}\right)$ & $\left(2.657^{* *}\right)$ & $\left(4.213^{* *}\right)$ & $\left(3.132^{* *}\right)$ \\
\hline Promotional Factor & .251 & .247 & .269 & .299 & .246 & .299 \\
& $\left(2.871^{* *}\right)$ & $\left(2.852^{* *}\right)$ & $\left(2.587^{* *}\right)$ & $\left(3.561^{* *}\right)$ & $\left(2.788^{* *}\right)$ & $\left(3.465^{* *}\right)$ \\
\hline Entertainment Factor & .232 & .250 & .256 & .241 & .230 & .222 \\
& $\left(2.137^{* *}\right)$ & $\left(2.865^{* *}\right)$ & $\left(2.877^{* *}\right)$ & $\left(2.145^{* *}\right)$ & $\left(2.121^{* *}\right)$ & $\left(2.809^{* *}\right)$ \\
\hline
\end{tabular}

** Significant at 0.01 level (2-tailed). *Standard coefficients show the effects of the three levers, such as awareness, exploration/expansion, and commitment, while novice was used as a base.

Table 7: Summary Of The Effects Of External Variables On The Perceived Usefulness (U) And Perceived Easy Of Use (EOU) By The Degree Of Involvement: Online Community (Awareness $N=91$, Exploration/Expansion $N=180$, Commitment $N=79$ )

\begin{tabular}{|l|c|c|c|c|c|c|}
\hline \multirow{2}{*}{ Variable } & \multicolumn{4}{|c|}{ Standard Coefficient* And Significance } \\
\cline { 2 - 7 } & \multicolumn{2}{|c|}{ Awareness } & \multicolumn{3}{c|}{ Cxploration/Expansion } & \multicolumn{3}{c|}{ Commitment } \\
\cline { 2 - 7 } & U & EOU & U & EOU & U & EOU \\
\hline Technology \& Usability Factor & .311 & .328 & .339 & .316 & .290 & .226 \\
& $\left(4.171^{* *}\right)$ & $\left(4.305^{* *}\right)$ & $\left(4.783^{* *}\right)$ & $\left(4.009^{* *}\right)$ & $\left(3.881^{* *}\right)$ & $\left(3.196^{* *}\right)$ \\
\hline Price Factor & .100 & .129 & .113 & .143 & .112 & .152 \\
& $(1.219)$ & $(1.289)$ & $(1.171)$ & $(1.988)$ & $(1.640)$ & $(1.721)$ \\
\hline Service Factor & .283 & .223 & .234 & .277 & .331 & .301 \\
& $\left(3.345^{* *}\right)$ & $\left(3.319^{* *}\right)$ & $\left(3.217^{* *}\right)$ & $\left(3.899^{* *}\right)$ & $\left(4.421^{* *}\right)$ & $\left(4.019^{* *}\right)$ \\
\hline Brand Name Factor & .289 & .293 & .228 & .262 & .315 & .233 \\
& $\left(3.415^{* *}\right)$ & $\left(3.571^{* *}\right)$ & $\left(3.445^{* *}\right)$ & $\left(3.751^{* *}\right)$ & $\left(4.113^{* *}\right)$ & $\left(3.432^{* *}\right)$ \\
\hline Promotional Factor & .301 & .347 & .209 & .297 & .243 & .287 \\
& $\left(4.375^{* *}\right)$ & $\left(4.523^{* *}\right)$ & $\left(2.987^{* *}\right)$ & $\left(3.941^{* *}\right)$ & $\left(3.186^{* *}\right)$ & $\left(3.765^{* *}\right)$ \\
\hline Entertainment Factor & .332 & .351 & .350 & .341 & .330 & .322 \\
& $\left(4.337^{* *}\right)$ & $\left(4.643^{* *}\right)$ & $\left(4.627^{* *}\right)$ & $\left(4.145^{* *}\right)$ & $\left(4.021^{* *}\right)$ & $\left(4.009^{* *}\right)$ \\
\hline
\end{tabular}

** Significant at 0.01 level (2-tailed). *Standard coefficients show the effects of the three levers, such as awareness, exploration/expansion, and commitment, while novice was used as a base. 
Table 8: The Effects Of Predictors On The Overall Attitudes Toward Online Communication Systems

\begin{tabular}{|l|c|c|c|}
\hline \multirow{2}{*}{ Predictors } & \multicolumn{3}{|c|}{ Standard Coefficient* And significance } \\
\cline { 2 - 4 } & E-mail & Messenger & Online Community \\
\hline Perceived Usefulness & $.378\left(4.915^{* *}\right)$ & $.391\left(5.013^{* *}\right)$ & $.380\left(4.980^{* *}\right)$ \\
\hline Perceived Easy of Use & $.365\left(4.637^{* *}\right)$ & $.379\left(4.952^{* *}\right)$ & $.376\left(4.817^{* *}\right)$ \\
\hline
\end{tabular}

** Significant at 0.01 level (2-tailed).

\section{Discussion And Conclusion}

This research paper explored users' attitudes toward online communication system and consumer satisfaction. Applying uses and gratification theory (Luo 2002) and Technology Acceptance Model (Davis 1989 and Davis, Bagozzi, and Warshaw 1989), this study investigated which factors affect online users' attitudes toward online communication system; how those factors affect perceived ease of use and usefulness; the effects of perceived ease of use and usefulness on overall attitudes toward communication system; and how online users' attitudes toward online communication system affect e-satisfaction. This study found important factors that affect online consumer attitudes toward the online communication system. The "technology/usability factor," "service factor," "brand name factor," "promotional factor," and "entertainment factor," are factors that affect online communication systems, including email, instant messenger, and community. This study also found that the price factor is not a significant factor for customers' attitudes toward online communication system.

The study has some limitations. Although this study uses multivariate statistics, such as factor and regression analysis and ANOCOVA, the study didn't measure the cause and effect relationship using a program, such as LISREL. The researchers will consider this issue in our future research. A framework to classify the different levels of involvement will be also developed and applied to measure consumer attitudes toward various websites. For further studies, a larger number of subjects will be considered.

The findings of this study contribute to the development of the uses and gratification theory and Technology Acceptance Model by applying it to the online users' attitudes toward communication system. Further, this study provides implications and offer suggestions to e-businesses dealing with online communication systems. The researchers expect that as a result of the regression analysis, factors will be found in this study that affect both perceived usefulness and ease of use (EOU). Further, it is expected that the impact of the factors on perceived usefulness and ease of use (EOU) will be significantly different according to the users' degree of involvement on the online communication systems. The findings of the study contribute to the development of the uses and gratification theory and Technology Acceptance Model, while also providing implications and suggestions to e-businesses.

\section{REFERENCE}

1. Ajzen, Icek and Fishbein, Martin (1980). Understanding Attitudes and Predicting Social Behavior Englewood Cliffs, NJ, Prentice-Hall.

2. Alba, Joseph, John Lynch, Barton Weitz, Chris Janiszewski, Richard Lutz, and Stacy Wood (1997), Interactive Home Shopping: Consumer, Retailer, and Manufacturer Incentives to Participate in Electronic Marketplaces, Journal of Marketing, (July) 61, 38-53.

3. Andrews, D., Preece, J. and Turoff, M. (2001), A Conceptual Framework for Demographic Groups Resistant to Online Community Interaction. Journal of Computer Mediated Communication.

4. Anonymous (1999), catalogue age magazine May.

5. Benbasat, I. And Dexter, A. S. (1986), An Investigation of the Effectiveness of Color and Graphical Presentation under Varying Time Constraints, MIS Quarterly, March, 59-84.

6. Bitner, M. J., Brown, Stephen W., and Meuter, Matthew L. (2000), Technology Infusion in Service Encounters, Journal of the Academy of Marketing Science, (Winter), 28, 1, 138-149.

7. Cardozo, Richard N. (1965), An Experimental Study of Customer Effort, Expectation, and Satisfaction, Journal of Marketing Research, 2, August 244-49. 
8. Chen, Qimei and Wells, William D. (1999), Attitudes Toward the Site, Journal of Advertising Research, September/October, p.27-37.

9. Cho, Y. and Fjermestad J. (2005), Using eCCRM to Maximize/Minimize Customer Satisfaction/Dissatisfaction, Advances in Management Information Systems: Special Issue on Customer Relationship Management, Summer.

10. Cho, Y. and Ha, J. (2004), Users' Attitudes Towards Movie-Related Websites and E-Satisfaction, Journal of Business \& Economics Research, March.

11. Cho, Y., Hiltz, S., and Im, I. (2003), The Determinants of Customer Propensity to Complain by Product Category on the Web, A Paper has been accepted at the Conference of Consumer Satisfaction, Dissatisfaction, and Complaining Behavior (June) and also appeared in the Journal of Consumer Satisfaction, Dissatisfaction, and Complaining Behavior, December.

12. Cho, Y., Im, I., Hiltz, S., and Fjermestad, J. (2002), An Analysis of Online Customer Complaints: Implications for Web Complaint Management, Proceedings of the $35^{\text {th }}$ Hawaii International Conference on System Sciences, January, Big Island, Hawaii.

13. Daft, R. L. and Lengel, R.H. (1986), Organizational Information Requirements, Media Richness, and Structural Design, Management Science, 32, 554-571.

14. Danet, Brenda, Wachenhauser, Tsameret, Bechar-Israeli, Haya, Cividalli, Amos, and Rosenbaum-Tamari, Yehudit (1996), Curtain Time 20:00 GMT: Experiments with Virtual Theater on Internet Relay Chat, Journal of Computer-Mediated Communication (JCMC), V. 2, N. 3, Dec., http://jcmc.huji.ac.il/vol2/ issue $3 /$

15. Davis, F. D. (1989), Perceived Usefulness, Perceived Ease of Use, and User Acceptance of Information Technology, MIS Quarterly, September, Vol.13, No.3, p.319-340.

16. Davis, F. D., Bagozzi, R. P., and Warshaw, P. R. (1989), User Acceptance of Computer Technology: A Comparison of Two Theoretical Models, in Management Science, August, Vol. 35, No. 8, p.982-1003.

17. Dewey, J. (1913), Play, in A Cyclopedia of Education, P. Monroe (ed.), Macmillan, NY, NY, p. 725-727.

18. Dick, A., Chakravarti, D., and Biehal, G. (1990), Memory-based Inferences During Consumer Choice, Journal of Consumer Research, Vol. 17, pp.82-93.

19. Dickson, G. W., DeSanctis, G., and McBride, D. J. (1986), Understanding the Effectiveness of Computer Graphics for Decision Support: A Cumulative Experimental Approach, Communication of ACM, 29, 40-47.

20. Dolan, Robert J. (2000), Priceline.com: Name Your Own Price, Harvard Business Review, November December.

21. Engel, J. F. and Blackwell, R. D. (1982), Consumer Behavior, $4^{\text {th }}$ ed., New York, Holt, Rinehart \& Winston.

22. Festinger, Leon (1957), A Theory of Cognitive Dissonance, Stanford, California: Stanford University Press.

23. Figueiredo, John M. de (2000), Finding Sustainable Profitability in Electronic Commerce," Sloan Management Review, Summer.

24. Franz, Charles. R. and Robey, Daniel C. (1986), Organizational Context, User Involvement, and the Usefulness of Information Systems, Decision Sciences, Summer, Vol.17, Issue 3, p.329-356.

25. Gardner, E. P., Young, P., and Ruth, S. R. (1989), Evolution of Attitudes Toward Computers: A Retrospective Review, Behavior and Information Technology, Vol.8, Issue 2, p. 89-98.

26. Hanson, Ward (2000), Principles of Internet Marketing, South-Western College Publishing.Helson, H. Adaptive-Level as a Basis for a Quantitative Theory of Frames of Reference. Psychological Review, 55, (1948), 297-313.

28. Helson, H. Adaptation-Level Theory in Psychology: A Study of a Science, 1, Sigmund Koch, (eds.), New York: McGraw-Hill, (1959).

29. Helson, H. Adaptation-Level Theory, New York: Harper \& Row, (1964).

30. Herzog, H (1944). What Do We Really Know About Day-Time Serial Listeners?: Radio Research. Paul F. Lazarsfeld, and Frank N. Stanton, (eds.), New York: Duel, Sloan and Pearce.

31. Hiltzik, Michael (1999), Dealers of Lightning: Xerox PARC and the Dawn of the Computer Age, New York: Harper Collins.

32. Hoffman, D. L., Novak, T., and Chatterjee, P. (1995), Commercial Scenarios for the Web: Opportunities and Challenges, Journal of Computer-Mediated Communication, $1,3$.

33. Howard, J. A. and Sheth, J. N (1969). The Theory of Buyer Behavior, New York, John Wiley and Sons.

34. Howard, G. S. and Smith, R. D. (1986), Computer Anxiety in Management Myth or Reality? Communications of the ACM, Vol. 29, Issue 7, July, p. 611-615. 
35. Hoffman, D. L., Novak, T., and Chatterjee, P. (1995), Commercial Scenarios for the Web: Opportunities and Challenges, Journal of Computer-Mediated Communication, $1,3$.

36. Keller, K. L. (1993), Conceptualizing, Measuring, and Managing Customer-Based Brand Equity, Journal of Marketing, Vol. 57, Issues 1.

37. Kim, Amy Jo. (2000), Community Building on the Web, Berkeley: Peachpit Press, 117.

38. Korgaonkar, Pradeep K. and Wolin, Lori D. (1999), A Multivariate Analysis of Web Usage, Journal of Advertising Research, March/April, 53-68.

39. Krishnamurthi, Lakshman and Raj, S. P. (1988), A Model of Brand Choice and Purchase Quantity Price Sensitivities, Marketing Science, Vol. 7, No. 1, Winter, 1-20.

40. Luo, X. (2002) Uses and Gratifications Theory and E-Consumer Behaviors: A Structural Equation Modeling Study. Journal of Interactive Advertising, 2, 2 Spring.

41. Malone, T.W. (1981) Toward a Theory of Intrinsically Motivating Instruction, Cognitive Science, 4, 333-369

42. McGaughey, Ronald E. and Mason, Kevin H. (1998), The Internet As A Marketing Tool, Journal of Marketing Theory and Practice, Summer.

43. Mcguire, W. J. (1974), Psychological Motives and Communication Gratification: The Uses of Mass Communications. Jay G. Blumler and Elihu Katz, eds., Beverly Hills, CA: Sage Publications.

44. Mohammed, Rafi. A., Fisher, Robert J., Jaworski, Bernard J., and Cahill, Aileen M. (2002), Internet Marketing: Building Advantage in a Networked Economy, McGraw-Hill Irwin, Marketspace U.

45. Oliver, R. L. and DeSarbo, Wayne S. (1988), Response Determinants in Satisfaction Judgments. Journal of Business Research, 14 March, 495-507.

46. Oliver, R. L. (1997), Satisfaction: A Behavioral Perspective on the Consumer. New York: Irwin/McGraw.

47. Rafaeli, S. (1986), The Electronic Bulletin Board: A Computer-Driven Mass Medium, Computers \& the Social Sciences, Vol. 2, Issue 3, p.123-131.

48. Reichheld, Frederick F. and Sasser, W. Earl, Jr. (1990), Zero Defections: Quality Comes to Services, Harvard Business Review, Boston, (September-October), 68, 5, 105-111.

49. __ and Phil Schefter (2000), E-Loyalty: Your Secret Weapon on the Web, Harvard Business Review, (July-August), 78, 4, 105-113.

50. Rice, R.E. (1993), Media Appropriateness: Using Social Presence Theory to Compare Traditional and New Organizational Media, Human Communication Research, 19, 4, 451-484.

51. Schubert, Petra and Dettling, Walter (2002), Extended Web Assessment Method (EWAM): Evaluation of ECommerce Applications from the Customers' Viewpoint, Proceedings of the $35^{\text {th }}$ Hawaii International Conference on System Sciences, Hawaii.

52. Schubert, Petra and Dorian Selz (1999), Web Assessment: Measuring the Effectiveness of Electronic Commerce Sites Going Beyond Traditional Marketing Paradigms, Proceedings of the $32^{\text {nd }}$ Hawaii International Conference on System Sciences.

53. Short, J., Williams, E. and Christie, B. (1976), The Social Psychology of Telecommunication, London: John Wiley and Sons.

54. Sproull, L.S. and Kiesler, S. (1991), Connections: New Ways of Working in the Networked Organization. Cambridge, MA: MIT Press.

55. Strauss, J., El-Ansary, A., and Frost, R. E-Marketing. Prentice Hall, $3^{\text {rd }}$ ed., (2003).

56. Ajzen, Icek and Fishbein, Martin (1980). Understanding Attitudes and Predicting Social Behavior Englewood Cliffs, NJ, Prentice-Hall.

57. Webster, Jane and Martocchio, Joseph J. (1992), Microcomputer Playfulness: Development of a Measure With Workplace Implications, MIS Quarterly, June, p.201-226.

58. Wellman, B. (1997), An Electronic Group is Virtually a Social Network, In S. Kiesler (Ed.), Culture of the Internet, Mahwah, N.J.: Lawrence Erlbaum Associates, 179-205.

59. Wellman, B. and Frank, K. (2001), Getting Support from Personal Communities, In N. Lin, R. Burt, and K. Cook (Eds.), Social capital: Theory and Research, Chicago, IL: Aldine De Gruytere.

60. Yi, Y. A Critical Review of Consumer Satisfaction. Review of Marketing, Valerie A. Zeithaml, (eds.), Chicago, American Marketing Association, (1990).

61. Zhou, Zheng (2002), Users' Attitudes Toward Web Advertising: Effects of Internet Motivation and Internet Ability, Advances in Consumer Research, Vol. 29, p. 71-78. 